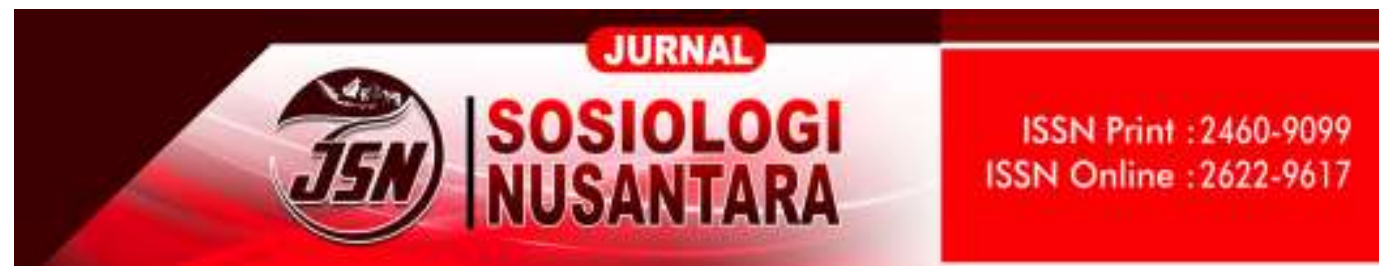

https://ejournal.unib.ac.id/index.php/jsn

DOI ://doi.org/10.33369/jsn.6.2.145-158

\title{
PERAN LELANG JABATAN DALAM MEWUJUDKAN BIROKRAT YANG BERKUALITAS
}

THE ROLE OF JOB AUCTION IN ORDER TO REALIZE QUALITY

\section{BUREAUCRATS}

\author{
Wulandari \\ wulandari@unib.ac.id
}

Fakultas Hukum, Universitas Bengkulu

\begin{abstract}
Abstrak
Perubahan hukum dapat mempengaruhi perubahan sosial sejalan dengan salah satu fungsi hukum, yakni sebagai sarana perubahan sosial atau sarana rekayasa masyarakat (social engineering). Salah satu sarana perubahan sosial yang saat ini dianggap sebagai solusi dari dari permasalahan birokrasi di pemerintahan adalah lelang jabatan. Penelitian ini menggunakan metode hukum normatif dengan pendekatan juridis normatif yang menitikberatkan penggunaan bahan/materi penelitian data sekunder didukung oleh data-data kepustakaan sebagai sumber utama. Penelitian ini menggunakan pendekatan konseptual. Hukum sebagai sarana perubahan masyarakat khususnya di Indonesia dapat dicontohkan dengan adanya sistem reformasi birokrasi yang baru yakni lelang jabatan. Pelaksanaan lelang jabatan pasca berlakunya Undang-Undang ASN telah memiliki dasar hukum kuat dan dalam pelaksanannya juga diawasi oleh sebuah lembaga non struktural yang bebas dari intervensi politik yaitu Komisi Aparatur Sipil Negara (KASN).
\end{abstract}

Kata Kunci : Birokrat yang Berkualitas, Lelang Jabatan 


\begin{abstract}
Legal changes can affect social change in line with one of the functions of law, namely as a means of social change or a means of social engineering. One of the means of social change currently considered a solution to bureaucratic problems in government is a position auction. This study uses a normative legal method with a normative juridical approach that emphasizes on the use of secondary data supported by library data as the main source. This research uses a conceptual approach. Law as a means of change in society, especially in Indonesia, can be exemplified by the existence of a new bureaucratic reform system, namely the auction of positions. Post-ASN Law enforcement has a strong legal basis and in its implementation it will also be supervised by a non-structural institution that is free from political intervention, namely the State Civil Apparatus Commission (KASN).
\end{abstract}

Keywords : Job Auction, Quality Bureaucrats

\title{
PENDAHULUAN
}

Gustav Radbruch menyebutkan tujuan hukum yang ingin dicapai dalam dalam suatu masyarakat adalah tercapainya keadilan, kemanfaatan dan kepastian hukum. Namun faktanya justru berbalik, masyarakat seringkali teraniaya dengan adanya kebijakan yang dibuat oleh pemerintah yang mengatasnamakan hukum. Dalam disiplin sosiologi hukum, terjadi hubungan antara perubahan sosial dalam masyarakat dengan sektor hukum. Hubungan antara perubahan sosial dan sektor hukum tersebut merupakan hubungan yang bertalian erat antara satu dengan yang lainnya, dalam arti perubahan sosial berpengaruh terhadap perubahan hukum, begitu pula sebaliknya perubahan hukum juga berpengaruh terhadap perubahan sosial. Perubahan hukum dapat mempengaruhi perubahan sosial sejalan dengan salah satu fungsi hukum, yakni sebagai sarana perubahan sosial atau sarana rekayasa masyarakat (social engineering) (Fuady, 2011).

Ada beberapa komponen yang dapat menjadi alat kontrol sosial, yakni merupakan alat untuk mengontrol perilaku masyarakat. Salah satunya adalah hukum. Alat kontrol sosial lainnya selain hukum adalah agama, moralitas, adat kebiasaan, pendidikan, kesenian, pers, keteladanan pemimpin, dan lain-lain. Karena hukum merupakan alat kontrol sosial, maka lembaga-lembaga hukum juga merupakan lembaga (agency) kontrol sosial (Fuady, 2011). 
Beberapa pendapat sarjana hukum yang berhaluan sosiologis telah mengemukakan pendapat terkait dengan peran hukum sebagai alat untuk mengubah masyarakat. Misalnya Roscoe Pound yang mempopulerkan istilah hukum sebagai alat perekayasa masyarakat, atau beberapa istilah hukum lain yang juga dipakai, seperti hukum sebagai agent of change atau social planning. Di masa pemerintahan Presiden Soeharto, di Indonesia muncul istilah hukum sebagai alat pembangunan (a tool of development), yang di kemukakan oleh Mochtar Kusumaatmaja, karena memang pada masa itu sektor hukum yang sangat di upayakan ikut mensukseskan pembangunan, namun sayangnya karena rendahnya kesadaran hukum dari para pembuat dan penegak hukum, menyebabkan hukum berubah fungsi dari yang tadinya hukum sebagai alat pembangunan berubah menjadi menjadi hukum sebagai alat untuk mengamankan pembangunan, yang mempunyai konsekuensi munculnya banyak hukum yang sangat represif dan melanggar hak-hak masyarakat, sehingga mengantarkan banyak aktivis ke rumah penjara atau liang kubur (Fuady, 2013).

Salah satu sarana perubahan sosial yang saat ini dianggap sebagai solusi dari permasalahan birokrasi di pemerintahan adalah lelang jabatan. Lelang jabatan atau seleksi dan promosi jabatan publik secara terbuka merupakan mekanisme yang dilakukan dalam pengangkatan pegawai negeri sipil (PNS) sebagai pejabat struktural berdasarkan prinsip profesionalisme. Mekanisme rekruitmen pejabat struktural sebelum populernya istilah lelang jabatan di Indonesia dilaksanakan menggunakan metode konvensional yang tertutup (closed system recruitment). Yang mana metode konvensional ini menimbulkan permasalahan di kemudian hari karena menempatkan seseorang pada jabatan yang tidak sesuai dengan bidang keahliannya. Dengan sistem rekruitmen yang tertutup ini juga mengedepankan alasan kedekatan dan kepatuhan kepada atasan, sehingga mengensampingkan alasan pemilihan yang sesuai dengan mekanisme yang sah dan sesuai dengan kualifikasi jabatan.

Istilah lelang jabatan ini populer pertama kali di era kepemimpinan Gubernur Jakarta Jokowi-Ahok. Jabatan di Pemerintah Provinsi DKI Jakarta yang dilelang pada kala itu jumlahnya mencapai 311 jabatan dengan rincian 44 jabatan 
148 IWulandari

Peran Lelang Jabatan Dalam Mewujudkan Birokrat Yang Berkualitas

camat dan 267 jabatan lurah (Sendhikasari D, 2013). Di Provinsi Bengkulu pada tahun 2020 mengadakan lelang jabatan terhadap 8 Jabatan Tinggi Pratama di lingkungan pemerintahan daerah Provinsi Bengkulu. Pengumuman adanya lelang jabatan, mekanisme pelaksanaan serta persyaratan yang harus dipenuhi calon pejabat yang ingin mengikuti proses lelang jabatan ini dapat diakses pada laman https://seleksijpt.bengkuluprov.go.id/\#. Pelaksanan lelang jabatan pemerintah daerah Bengkulu ini sejalan dengan amanah dari Peraturan Menteri Pendayagunaan Aparatur Negara dan Reformasi Birokrasi Nomor 15 Tahun 2019 tentang Tata Cara Pengisian Jabatan Pimpinan Tinggi Secara Terbuka dan Kompetitif di Lingkungan Instansi Pemerintah, Surat Menteri Dalam Negeri Nomor: 821/3036/OTDA Tanggal 15 Juni 2020 perihal Persetujuan Seleksi Terbuka Jabatan Pimpinan Tinggi Pratama dan Penjelasan Mutasi di Lingkungan Pemerintah Daerah.

Pada hakikatnya, lelang jabatan memiliki payung hukum yang sah, yakni Undang-Undang Nomor 5 Tahun 2014 tentang Aparatur Sipil Negara, Peraturan Menteri Pendayagunaan Aparatur Negara dan Reformasi Birokrasi Nomor 15 Tahun 2019 tentang Tata Cara Pengisian Jabatan Pimpinan Tinggi Secara Terbuka dan Kompetitif di Lingkungan Instansi Pemerintah dan peraturan perundangan lain yang menunjang jalannya lelang jabatan di Indonesia. Dengan adanya legalitas yang diatur dalam peraturan perundang-undangan, maka selayaknya lelang jabatan menjadi alat perubahan sosial dalam rangka menjadikan birokrasi di pemerintahan lebih baik. Tulisan ini bertujuan untuk memaparkan peran lelang jabatan dalam mewujudkan birokrat yang berkualitas dilihat dari aspek hukum dan sosiologi hukum dalam rangka mewujudkan good governance sebagaimana yang dicita-citakan dalam konstitusi negara Indonseia.

\section{METODE PENELITIAN}

Penelitian yang dilaksanakan merupakan penelitian hukum normatif dengan metode pendekatan juridis normatif yang menitikberatkan penggunaan data sekunder didukung oleh data-data kepustakaan sebagai sumber utama, yaitu dengan membaca dan mempelajari buku-buku, peraturan perundang-undangan, 
konvensi-konvensi internasional serta tulisan-tulisan lainnya yang berkaitan dengan lelang jabatan. Di samping itu, penelitian ini menggunakan pendekatan konseptual (conseptual approach). Dalam penelitian ini, penggunaan konseptual ditujukan untuk mengetahui peran lelang jabatan dalam rangka untuk mewujudkan birokrasi yang baik.

Penelitian ini termasuk dalam spesifikasi penelitian deskriptif analisis, yakni penelitian menggambarkan kemudian menganalisis permasalahan yang berhubungan dengan konsep lelang jabatan di Indonesia, kemudian akan digambarkan bagaimana konsep lelang jabatan sebagai law as a tool of social engineering di Indonesia dalam mewujudkan birokrat yang berkualitas. Teknik pengumpulan data primer digunakan melalui studi kepustakaan. Data primer yang dimaksud dalam penelitian ini adalah peraturan perundang-undangan yang mengatur terkait pelaksanaan lelang jabatan di Indonesia. Data sekunder diperoleh dari publikasi ilmiah berupa buku teks, kamus hukum serta jurnal hukum. Data tersiser diperoleh melalui hasil wawancara, artikel yang berasal dari majalah atau koran serta internet. Semua data yang telah diperoleh dari data primer, sekunder dan tersier kemudian dianalisis secara normatif kualitatif. Normatif kualitatif memiliki arti bahwa penelitian didasarkan pada asas hukum serta norma hukum yang diperoleh kemudian dianalisis guna mendapatkan gambaran yang jelas terkait dengan permasalahan yang diteliti.

\section{PEMBAHASAN}

\section{Konsep Lelang Jabatan di Indonesia}

Pada era reformasi saat ini, prioritas utama bagi rakyat dan pemerintahan Indonesia adalah upaya mewujudkan sistem pemerintahan yang demokratis, bersih, dan berwibawa. Salah satu upaya untuk mereformasi sistem pemerintahan adalah penataan aparatur pemerintah (Hartini, 2010). Mereformasi birokrasi artinya adanya keterkaitan yang erat dengan pengaturan secara komprehensif dan sistematis mengenai jabatan-jabatan dalam pemerintahan baik ditingkat pusat, provinsi maupun kabupaten/kota. Oleh karenanya, untuk mencapai tujuan 
150 IWulandari

Peran Lelang Jabatan Dalam Mewujudkan Birokrat Yang Berkualitas

reformasi birokrasi yang tepat, maka diperlukan mekanisme pengisian jabatanjabatan secara baik dan profesional.

Pembaharuan sistem ketatanegaraan dapat diaktualisasikan dengan perubahan paradigma penyelenggaraan pemerintahan melalui pengaturan secara komprehensif mengenai jabatan pemerintahan yang dapat mengagregasi secara tepat kebutuhan dan kepentingan warga masyarakat. Oleh karena itu, adanya perubahan konsep dalam struktur pemerintahan, juga perlu dilakukan upaya untuk menempatkan orang-orang atau aparatur yang tepat dalam mengisi jabatan dalam struktur pemerintahan tersebut (the right man on the right position) dalam upaya untuk menyempurnakan reformasi birokrasi yang dikehendaki. Hal ini sejalan dengan pandangan Plato yang berjudul The Laws. Plato mengemukakan agar negara diperintah oleh orang-orang bebas dan cendekia, dikarenakan Plato menyadari sulitnya mendapatkan orang dengan kualitas itu. Kemudian Plato berpandangan bahwa negara harus melaksanakan keadilan berdasarkan kaidahkaidah tertulis (Ali, 2002).

Terobosan tindakan pemerintah dengan melakukan metode pengisian jabatan secara terbuka atau yang lazim disebut dengan istilah lelang jabatan merupakan usaha untuk mengatasi problematika pengisian jabatan struktural demi menjamin implementasi hak asasi setiap orang dalam pemerintahan. Tujuan penempatan orang pada jabatan sesuai dengan kualifikasinya merupakan kebijakan reformis dalam memberantas nepotisme dalam bidang kepegawaian.

Sejak diundangkan Undang-Undang Nomor 5 Tahun 2014, Indonesia memasuki babak baru dalam sistem, model dan bahkan paradigma birokrasi. Kehadiran undang-undang ini merupakan upaya menjawab berbagai permasalahan yang selama ini dihadapi oleh sistem birokrasi di Indonesia yang dinilai banyak bermasalah, sehingga tujuan utama birokrasi (yang dalam hal ini PNS) dalam upaya menciptakan kesejahteraan masyarakat melalui berbagai model dan bentuk pelayanan publik, dinilai telah tercederai oleh banyak hal. Contohnya, dengan eratnya kaitan birokrasi dengan berbagai kepentingan politik dari para penguasa yang sedang berkuasa, adanya diskriminasi baik berbasis pada suku, agama maupun ras. 
Peraturan Menteri Pendayagunaan Aparatur Negara dan Reformasi Birokrasi Republik Indonesia Nomor 13 Tahun 2014 tentang Tata Cara Pengisian Jabatan Pimpinan Tinggi Secara Terbuka Di Lingkungan Instansi Pemerintah menyebutkan dalam lampirannya bahwa jabatan pimpinan tinggi utama dan madya pada kementerian, kesekretariatan lembaga negara, lembaga nonstruktural, dan instansi daerah di isi dan dilakukan secara terbuka dan kompetitif di kalangan PNS dan memenuhi syarat kompetensi, kualifikasi, kepangkatan, pendidikan dan latihan, rekam jejak jabatan, dan integritas serta persyaratan lain yang dibutuhkan sesuai dengan ketentuan peraturan perundang-undangan dan dilakukan pada tingkat nasional.

Pada hakikatnya, pengisian jabatan dalam pemerintahan berkaitan erat dengan hak setiap orang, yang merupakan pengejawantahan dari hak politik sebagai bagian dari hak asasi manusia yang harus diakui dan dilindungi oleh negara. Di negara Indonesia dalam Pasal 28D UUD Tahun 1945 tersebut dengan jelas bahwa setiap warga negara memiliki kesempatan yang sama untuk turut serta dalam pemerintahan. Pengaturan pengisian jabatan pemerintahan secara yuridis telah dijabarkan dalam : 1). Undang-Undang Nomor 5 Tahun 2014 tentang Aparatur Sipil Negara, 2). Peraturan Pemerintah Nomor 9 Tahun 2003 tentang Wewenang Pengangkatan, Pemindahan, Pemberhentian Pegawai Negeri Sipil, 3). Peraturan Pemerintah Nomor 13 Tahun 2002 tentang Perubahan Peraturan Pemerintah Nomor 100 Tahun 2000 tentang Pengangkatan Pegawai Negeri Sipil Dalam Jabatan Struktural, 4). Peraturan Menteri Pendayagunaan Aparatur Negara dan Reformasi Birokrasi Nomor 15 Tahun 2019 tentang Tata Cara Pengisian Jabatan Pimpinan Tinggi Secara Terbuka dan Kompetitif di Lingkungan Instansi Pemerintah.

Selanjutnya dalam Pasal 72 ayat (2) Undang-Undang Nomor 5 Tahun 2014 menyatakan bahwa setiap PNS yang memenuhi syarat mempunyai hak yang sama untuk dipromosikan ke jenjang jabatan yang lebih tinggi. Pengangkatan dalam jabatan ini berdasarkan atas prestasi kerja, disiplin kerja, kesetiaan, pengabdian, pengalaman, dapat dipercaya, serta syarat-syarat objektif lainnya yang dimiliki oleh PNS. Penjaminan objektifitas dalam mempertimbangkan dan menetapkan 
152 IWulandari

Peran Lelang Jabatan Dalam Mewujudkan Birokrat Yang Berkualitas

kenaikan pangkat dan pengangkatan dalam jabatan didasarkan pada daftar penilaian pelaksanaan pekerjaan dan daftar urut kepangkatan.

Kemudian Pasal 1 angka 4 Peraturan Pemerintah Nomor 9 Tahun 2003 tentang Wewenang Pengangkatan, Pemindahan, Pemberhentian Pegawai Negeri Sipil, menyatakan bahwa Gubernur adalah Pejabat Pembina Kepegawaian Daerah. Selanjutnya dalam Pasal 3 Peraturan Pemerintah Nomor 9 Tahun 2003 tentang Wewenang Pengangkatan, Pemindahan, Pemberhentian Pegawai Negeri Sipil Pejabat Pembina Kepegawaian Daerah Propinsi atau Kabupaten/Kota menetapkan: (a) pengangkatan Calon Pegawai Negeri Sipil Daerah di lingkungannya; (b) pengangkatan menjadi Pegawai Negeri Sipil Daerah bagi Calon Pegawai Negeri Sipil Daerah di lingkungannya, kecuali yang tewas atau cacat karena dinas. Pejabat sebagaimana dimaksud dapat mendelegasikan wewenangnya dengan cara memberikan kuasa kepada pejabat lain di lingkungannya.

Pasal 5 Peraturan Pemerintah Nomor 100 Tahun 2000 Tentang Pengangkatan Pegawai Negari Sipil Dalam Jabatan Struktural menyebutkan beberapa persyaratan substansial dalam menduduki jabatan struktural, yakni sebagai berikut: 1). Berstatus Pegawai Negeri Sipil.,2). Serendah-rendahnya menduduki pangkat 1 (satu) tingkat dibawah jenjang pangkat yang ditentukan, 3). Memiliki kualifikasi dan tingkat pendidikan yang ditentukan, 4). Semua unsur penilaian prestasi kerja sekurang-kurangnya bernilai baik dalam dua tahun terakhir, 5). Memiliki kompetensi jabatan yang diperlukan, 6). Sehat jasmani dan rohani.

Selain persyaratan sebagaimana dimaksud dalam pasal 5 Peraturan Pemerintah tersebut, disebutkan pula dalam Pasal 7 bahwa pejabat pembina kepegawaian pusat dan pejabat pembina kepegawaian daerah perlu memerhatikan faktor senioritas dalam kepangkatan, usia, pendidikan dan pelatihan jabatan serta pengalaman yang dimiliki. Pegawai Negeri Sipil yang diangkat dalam jabatan struktural yang belum mengikuti dan lulus pendidikan dan pelatihan kepemimpinan sesuai dengan tingkat jabatan struktural wajib mengikuti dan lulus 
pendidikan dan pelatihan kepemimpinan selambatlambatnya 12 (dua belas) bulan sejak yang bersangkutan dilantik.

Peraturan Menteri Pendayagunaan Aparatur Negara dan Reformasi Birokrasi Nomor 15 Tahun 2019 tentang Tata Cara Pengisian Jabatan Pimpinan Tinggi Secara Terbuka dan Kompetitif di Lingkungan Instansi Pemerintah menyatakan bahwa sesuai Grand Design Reformasi Birokrasi yang dipertajam dengan rencana aksi Program Percepatan Reformasi Birokrasi salah satu diantaranya adalah Program Sistem Promosi PNS secara terbuka. Lebih lanjut disebutkan dalam Surat Edaran tersebut, bahwa sehubungan dengan ketentuan sebagaimana tersebut di atas, perlu diadakan promosi PNS atau pengisian jabatan berdasarkan sistem merit dan terbuka, dengan mempertimbangkan kesinambungan karier PNS yang bersangkutan guna lebih menjamin para pejabat struktural memenuhi kompetensi jabatan yang diperlukan oleh jabatan tersebut.

Jabatan struktural yang menjadi objek kajian dalam hal ini lurah dan camat. Peraturan Gubernur DKI Jakarta No. 19 Tahun 2013 Tentang Seleksi Terbuka Camat dan Lurah menyatakan bahwa seleksi pengisian jabatan struktural lurah dan camat dilaksanakan secara terbuka. Pasal 1 angka 12 kemudian menyebutkan bahwa seleksi terbuka adalah proses pemilihan yang diumumkan secara luas melalui media bagi PNS yang memenuhi syarat untuk diangkat dalam jabatan camat atau lurah. Selanjutnya pada Pasal 4 disebutkan bahwa seleksi terbuka Camat dan Lurah dilakukan dengan prinsip objektif, transparan, dan akuntabel.

Lelang jabatan dalam Undang-Undang ASN dapat ditemukan dalam Bab IX mulai dari pasal 108 sampai pasal 115 dan dijabarkan lebih lanjut dalam Permenpan-RB No.13 Tahun 2014 tentang Tata Cara Pengisian Jabatan Pimpinan Tinggi Secara Terbuka di Lingkungan Pemerintah. Lelang Jabatan sebagaimana dimaksud dalam Undang-Undang ASN hanya dilakukan untuk mengisi jabatan pimpinan tinggi atau pejabat struktural, eselon 1 dan 2.

Pelaksanaan lelang jabatan pasca berlakunya Undang-Undang ASN telah memiliki dasar hukum kuat dan juga akan diawasi oleh lembaga non struktural yang bebas dari intervensi politik yaitu Komisi Aparatur Sipil Negara (KASN). Pelaksanaan lelang jabatan harus mendapat dukungan penuh dikarenakan lebih 
154 IWulandari

Peran Lelang Jabatan Dalam Mewujudkan Birokrat Yang Berkualitas

mencerminkan asas keadilan dan lebih dapat menjamin penerapan sistem merit yang berdasarkan kompetensi, kualifikasi dan profesionalisme dalam manjemen ASN, terlepas dari kelemahan pengaturan lelang jabatan yang mungkin masih terdapat dalam Undang-Undang ASN.

Beberapa dampak pengisian jabatan melalui sistem lelang dapat diuraikan sebagai berikut: Pertama, mendapatkan outcome positif yaitu terpilihnya PNS yang memiliki kompetensi dan profesionalitas yang sesuai dengan jabatannya sekaligus memiliki hati nurani yang bersih dan juga memiliki rekam jejak yang baik. Kedua, pelaksanaan fit and proper test dalam pengisian jabatan menyebabkan persaingan positif akan terbuka. Ketiga, bagi pejabat pembina kepegawaian dan pejabat eselon 1, 2 yang berwewenang dalam memberi mandat bagi PNS dalam jabatan tertentu, lelang jabatan dapat bermanfaat untuk menghindarkan diri dari intervensi berbagai pihak yang berusaha menempatkan orangnya dalam jabatan strategis di lingkungan masing-masing.

\section{Penerapan Law As Tool Of Social Engineering di Indonesia}

Hubungan antara perubahan sosial dengan sektor hukum merupakan hubungan yang terkait satu dengan lainnya, dalam arti terdapat pengaruh antara perubahan sosial terhadap perubahan sektor hukum, begitu pula sebaliknya, perubahan hukum juga berpengaruh terhadap perubahan sosial. Perubahan hukum yang dapat mempengaruhi perubahan sosial sejalan dengan salah satu fungsi hukum, yakni sebagai sarana perubahan sosial, atau sarana merekayasa masyarakat (social engineering). Suatu istilah yang pertama dicetuskan oleh ahli hukum Amerika yang terkenal yaitu Roscoe Pound menyebutkan hukum merupakan sarana rekayasa masyarakat (a tool of social engineering) (Fuady, 2013).

Roscoe Pound memiliki pendapat mengenai hukum yang menitik beratkan pada kedisiplinan dengan teorinya yaitu Law as a tool of social engineering (hukum adalah alat untuk memperbaharui atau merekayasa masyarakat). Untuk dapat memenuhi peranannya Roscoe Pound lalu membuat penggolongan atas 
kepentingan-kepentingan yang harus dilindungi oleh hukum itu sendiri, yaitu sebagai berikut (Meda, 2014):

1. Kepentingan Umum (Public Interest)
a. Kepentingan negara sebagai Badan Hukum
b. Kepentingan negara sebagai penjaga kepentingan masyarakat.

\section{Kepentingan Masyarakat (Social Interest)}
a. Kepentingan akan kedamaian dan ketertiban
b. Perlindungan lembaga-lembaga sosial
c. Pencegahan kemerosotan akhlak
d. Pencegahan pelanggaran hak
e. Kesejahteraan sosial.

\section{Kepentingan Pribadi (Private Interest)}
a. Kepentingan individu
b. Kepentingan keluarga
c. Kepentingan hak milik.

Hukum sebagai alat rekayasa sosial (law as a tool of social engineering and social control) yang dikemukakan oleh Roscoe Pound, memiliki tujuan untuk menciptakan harmoni dan keserasian agar secara optimal dapat memenuhi kebutuhan dan kepentingan manusia dalam masyarakat. Keadilan adalah lambang usaha penyerasian yang harmonis dan tidak memihak dalam mengupayakan kepentingan anggota masyarakat yang bersangkutan. Untuk kepentingan yang ideal itu diperlukan kekuatan paksa yang dilakukan oleh penguasa negara (Meda, 2014).

Definisi law as a tool of social engineering dapat pula dimaknai sebagai sarana yang ditujukan untuk mengubah perilaku warga masyarakat, sesuai dengan tujuan- tujuan yang telah ditetapkan sebelumnya (Soerjono, 2009). Penggunaan hukum yang telah dilakukan secara sadar oleh masyarakatnya merupakan ciri yang menonjol dalam masyarakat modern. Hukum tidak hanya digunakan untuk mengukuhkan pola-pola kebiasaan dan tingkah laku yang terdapat dalam masyarakat, melainkan juga untuk mengarahkannya kepada tujuan-tujuan yang dikehendaki, menghapuskan kebiasaan yang dipandangnya tidak sesuai lagi, 
156 IWulandari

Peran Lelang Jabatan Dalam Mewujudkan Birokrat Yang Berkualitas

menciptakan pola-pola kelakuan baru dan sebagainya. Pandangan inilah yang disebut sebagai pandangan modern tentang hukum itu yang menjurus kepada penggunaan hukum sebagai instrumen yaitu law as a tool social engineering (Rahardjo, 2006)

Hukum sebagai sarana perubahan masayarakat khususnya di Indonseia dapat dicontohkan dengan adanya sistem reformasi birokrasi yang baru yakni lelang jabatan. Pada hakikatnya istilah lelang jabatan bukan merupakan bahasa hukum. Dalam peraturan perundang-undangan yang berlaku khususnya peraturan perundang-undangan di bidang hukum kepegawaian tidak ditemukan istilah lelang jabatan secara eksplisit (letterlijk). Dimulai pada masa Gubernur DKI Jakarta Joko Widodo mewacanakan lelang jabatan camat dan lurah di wilayahnya, istilah lelang jabatan semakin popular di kalangan masyarakat.

Lelang jabatan memiliki pengertian yang hampir sama dengan open recruitment atau open bidding. Open recruitment maupun open bidding atau lelang jabatan sebenarnya bukan hal baru dalam perspektif administrasi publik. Dalam konsep New Public Management (NPM), metode ini sudah dikenalkan dan dipraktekkan di negara-negara barat, seperti New Zealand, namun dengan penyebutan istilah dan nama yang berbeda-beda di masing-masing negara (Soerjono, 2009).

Demi mewujudkan birokrasi yang berkualitas, pelaksanaan lelang jabatan di Indonesia memiliki dasar hukum yang sah, dan di lihat dari aspek sosiologi hukum, lelang jabatan merupakan suatu sarana yang menjadi perubahan sosial di masyarakat. Pemahaman terhadap kondisi sosial masyarakat dan analsis fungsional effektivitasnya harus mendapat perhatian dengan seksama dalam penggunaan hukum sebagai alat/instrumen rekayasa sosial. Oleh karena itu, perlu adanya identifikasi permasalahan hukum yang dinilai memerlukan prioritas untuk dilakukan pembaharuan yang antara lain diklasifikasikan sebagai berikut:

a. Permasalahan yang langsung menyangkut kehidupan pribadi sesorang dan erat kaitannya dengan kehidupan budaya dan spiritual masyarakat yang sering diistilahkan dengan bidang hukum yang non-netral, karena mengandung aspek emosional, psikologis, dan magis religius; 
b. Permasalahan yang bertalian erat dengan kemajuan masyarakat pada umumnya, misalnya hukum perseroan, hukum kontrak, hukum lalu lintas, atau lebih dikenal dengan istilah bidang hukum yang netral yang dilihat dari aspek budaya akan lebih mudah untuk ditangani.

Dari klasifikasi di atas, jelas bahwa lelang jabatan berkorelasi dengan kemajuan masayarakat, yang dapat ditempuh dengan berbagai cara dan upaya, salah satunya adalah reformasi birokrasi. Perwujudan birokrasi yang berkualitas diperoleh dengan cara menempatkan pejabat sesuai dengan bidang keahliannya, sehingga tujuan negara dalam menjalankan good governance bisa terwujud.

\section{KESIMPULAN}

Perubahan hukum dapat mempengaruhi perubahan sosial. Pernyataan ini sejalan dengan salah satu fungsi hukum, yakni sebagai sarana perubahan sosial, atau sarana merekayasa masyarakat (social engineering). Jadi, hukum merupakan sarana rekayasa masyarakat (a tool of social engineering). Salah satu bentuk rekayasa masyarakat adalah lelang jabatan dalam rangka memperoleh birokrat yang berkualitas. Birokrat yang berkualitas diperoleh dengan cara mereformasi birokrasi. Reformasi birokrasi memiliki korelasi yang erat dengan pengaturan secara komprehensif dan sistematis mengenai jabatan-jabatan dalam pemerintahan, baik ditingkat pusat, provinsi maupun kabupaten/kota. Oleh karenanya, untuk mencapai reformasi birokrasi yang tepat maka diperlukan mekanisme pengisian jabatan-jabatan secara tepat pula. Salah satu bentuk reformasi birokrasi adalah lelang jabatan. Lelang jabatan struktural adalah bentuk dari promosi jabatan yang dilakukan secara transparan dan selektif. Lelang jabatan memiliki nilai positif dalam reformasi birokrasi yaitu untuk merekrut ataupun menempatkan pejabat eselon yang memiliki kompetensi dan profesionalitas yang memadai 
Peran Lelang Jabatan Dalam Mewujudkan Birokrat Yang Berkualitas

\section{DAFTAR PUSTAKA}

Ali, A. 2002. Menguak Tabir Hukum (Suatu Kajian Filosofis dan Sosiologis). Toko Gunung Agung.

Fuady, M. 2011. Sosiologi Hukum Kontemporer: "Interaksi Hukum, Kekuasaan, dan Masyarakat.” Kencana.

Fuady, M. 2013. Teori-Teori Besar (Grand Theory) Dalam Hukum. Kencana.

Hartini, S. dkk. 2010. Hukum Kepegawaian di Indonesia. Sinar Grafika.

https://seleksijpt.bengkuluprov.go.id/\#

Meda, A. 2014. Sosiologi Hukum (Aliran Sociological jurisprudence). Http://Akhyar13.Blogspot.Com.

http://akhyar13.blogspot.com/2014/05/sosiologi-hukum-aliran-

sociological.html

Peraturan Pemerintah Nomor 9 Tahun 2003 tentang Wewenang Pengangkatan, Pemindahan, Pemberhentian Pegawai Negeri Sipil.

Peraturan Pemerintah Nomor 13 Tahun 2002 tentang Perubahan Peraturan Pemerintah Nomor 100 Tahun 2000 tentang Pengangkatan Pegawai Negeri Sipil Dalam Jabatan Struktural.

Peraturan Pemerintah Nomor 100 Tahun 2000 tentang Pengangkatan Pegawai Negari Sipil Dalam Jabatan Struktural.

Peraturan Menteri Pendayagunaan Aparatur Negara dan Reformasi Birokrasi Nomor 15 Tahun 2019 tentang Tata Cara Pengisian Jabatan Pimpinan Tinggi Secara Terbuka dan Kompetitif di Lingkungan Instansi Pemerintah.

Peraturan Gubernur DKI Jakarta No. 19 Tahun 2013 Tentang Seleksi Terbuka Camat dan Lurah.

Rahardjo, S. 2006. Ilmu Hukum. Citra Aditya Bakti.

Sendhikasari D, D. 2013. Lelang Jabatan Camat dan Lurah di DKI Jakarta. $V(09), \quad 2009-2012 . \quad$ Link dapat diakses : http://berkas.dpr.go.id/puslit/files/info_singkat/Info\%20Singkat-V-9-I-P3DIMei-2013-38.pdf

Soerjono, S. 2009. Pokok-Pokok Sosiologi Hukum. Rajawali Pers.

Undang-Undang Nomor 5 Tahun 2014 tentang Aparatur Sipil Negara. 